\title{
La última tentación de la libertad: vida y andanzas de la obra de Nikos Kazantzakis en tiempos de censura
}

\author{
PaOla Laskaris \\ Universidad de Bari
}

Título: La última tentación de la libertad: vida y andanzas de la obra de Nikos Kazantzakis en tiempos de censura.

Resumen: Del célebre escritor y traductor griego Nikos Kazantzakis -creador del mítico Zorbaquizás se conozca su intensa relación con España, su cultura y su historia. Sin embargo, poco o nada se sabe del largo y atormentado periplo de sus obras en plena dictadura franquista, cuando su pluma, vibrante y heterodoxa, se enfrentó con el riguroso dogmatismo de la censura. El rico e importante caudal de documentos conservados en el Archivo General de Administración de Alcalá de Henares nos permite, por un lado, reconstruir con precisión el complejo entramado de la circulación de su obra a partir de los ańos cincuenta y, por otro, brindar un ejemplo más de las modalidades de la censura editorial y sus repercusiones a medio y largo plazo, descubriendo que hasta los años ochenta un lector español accedía a la obra de Kazantzakis casi exclusivamente a través de las Obras selectas de la editorial Planeta, variamente enmendadas e intervenidas.

Palabras clave: Kazantzakis, España, Franquismo, Censura.

Fecha de recepción: 20/11/2017.

Fecha de aceptación: 13/12/2017.
Title: Last Temptation of Freedom: Life and Wanderings of Nikos Kaatzakis's Work in Censorship Times.

Abstract: The strong relationship between Spain, its culture and history, and Nikos Kazantzakis, the renowned Greek writer and translator, creator of the mythical Zorba, is likely to be well-known. However, we know little or nothing about the long and tormented trajectory of his works during the Franco regime, when his heretodoxical pen had to struggle with the tough dogmatism of the censorship. The huge and significant amount of documents, kept in the Archivo General de Administracion of Alcalá de Henares, allows us, on the one hand, to precisely reconstruct the complex network of the circulation of his works, since the fifties and, on the other hand, provides us one more example of the patterns of the censorship on the publishing sector and its impact, in the medium and short term. Thus we could discover that, till the eighties, the Spanish reader could access Kazantzakis's works, almost exclusively through his Obras selectas, published by Planeta, emended and modified in different ways.

Key words: Kazantzakis, Spain, Francoism, Censorship.

Date of Receipt: 20/11/2017.

Date of Approval: 13/12/2017. 
He escrito series de artículos, he publicado libros, he hablado con imparcialidad constante y frecuentemente severa. Y no he satisfecho ni a comunistas ni a burgueses. Poco importa. No era mi finalidad complacer, sino decir la verdad. [...] Hagáis lo que hagáis y transcurra el tiempo que transcurra, señores Jueces, tengo la convicción de que siempre crecerá la minoría, siempre verán aumentar su fuerza las víctimas y siempre caerá la clase que golpee. Tal es mi pensamiento. He creído mi deber formularlo con sinceridad absoluta. En cuanto al vuestro, si consideráis que debo ser castigado, castigadme.

Nikos Kazantzakis, Apología, Creta, $1925^{1}$

En su epitafio, que yace como un libro abierto bajo el sol radiante de Creta, queda grabada su firme y orgullosa filosofía de vida: "No espero nada, no temo nada, soy libre". A sesenta años de la muerte de Nikos Kazantzakis (1883-1957) —el creador del imperecedero y sanchoquijotesco Zorba-, su obra sigue representando la quintaesencia del librepensamiento y la agonía homérica (y unamuniana) del hombre, constantemente impulsado a ir más adentro de sí mismo².

Si por un lado Kazantzakis fue apreciado y alabado internacionalmente por su extraordinaria lucidez y por su estilo, visionario y diáfano a la vez,

1 El texto integral de su Apología puede leerse en: Eleni N. Kazantzakis, Kazantzaki el disidente visto a través de sus cartas, sus notas, sus textos inéditos, Barcelona, Planeta, 1974, pp. 455-461.

2 Sobre el autor y su obra véanse las páginas web oficiales del Museo Nacional Kazantzaki (www.kazantzaki.gr), del Museo Histórico de Creta (https://www.historical-museum.gr/webapps/kazantzakis-pages/en/introduction/intro.php） y de las Ediciones Kazantzakis (www.kazantzakispublications.org), que brindan informaciones biográficas y bibliográficas detalladas. Véase además la edición de la correspondencia del autor con el amigo y escritor Prevelakis, que ofrece un testimonio

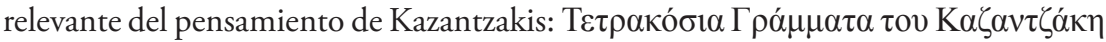

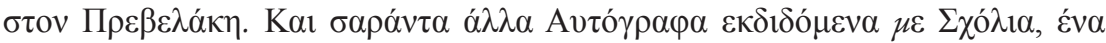

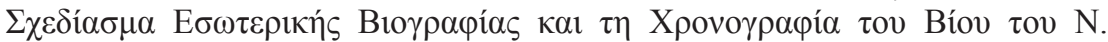

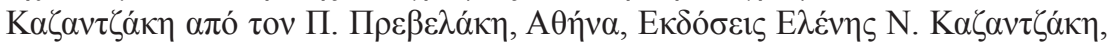

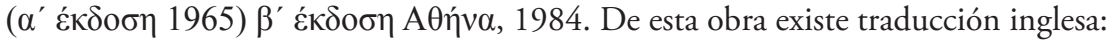
The Selected Letters of Nikos Kazantzakis, ed. y trad. Peter Bien, Princeton, Princeton University Press, 2012. 
por otro cayó también en la estrecha red del dogmatismo ideológico más conservador, que juzgó la excentricidad de visión y expresión del gran escritor griego una intolerable forma de heterodoxia y disidencia, inevitablemente censurable:

The fervour with which this timid and kind-hearted man was persecuted by both Church and State is unwarranted. Government officials intervened so that he would not be awarded the Nobel Prize he so rightfully deserved. [...] As Nikos Kazantzakis searched for God, church officials searched his books for phrases which strayed from doctrine. They always found something, on one occasion, without even having to open one of his books. In 1954, the Greek Orthodox Church of America convened to condemn The Last Temptation of Christ as "indecent, atheistic and treasonable". [...] In April 1954, The Last Temptation of Christ was included in the notorious and widely dreaded Index of forbidden books of the Vatican, the Index Librorum Prohibitorum. Kazantzakis responded with a letter to the Index Committee of the Vatican City with a quote by Tertullian: "Ad tuum, Domine, tribunal appello" ("At Your court, Lord, I make my appeal"). The Greek Orthodox Church had already launched its own relentless persecution against him long before that, since 1927, with the publication of his Saviors of God. The rumours that Nikos Kazantzakis has been excommunicated endure and propagate to this day. Nikos Kazantzakis was indeed vilified, called an "atheist," accused of heresy, of blasphemy and irreverence, but was never excommunicated by the Greek Orthodox Church. [...] In a letter to the Holy Synod Nikos Kazantzakis replied to these allegations: "You have execrated me, Holy Fathers; I bless you. I pray that your conscience may be as clean as mine and that you may be as moral and as religious as I am”. In 1968, the Ecumenical Patriarch Athinagoras stated that "Nikos Kazantzakis's books adorn the Patriarchal Library»"

Según aclara Kimon Friar — que tradujo al inglés su personal catecismo

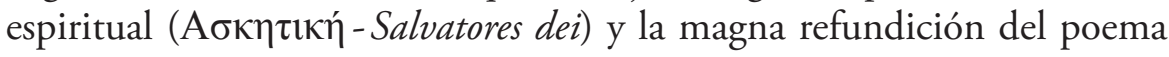

3 Niki P. Stavrou, A Glance upon his Life, texto publicado en la página web oficial de las Ediciones Kazantzakis (http://www.kazantzakispublications.org/en/kazantzakis. php\#). Véase también la carta que Kazantzakis dirigió a Prevelakis en mayo de 1954

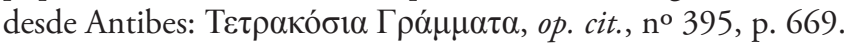


homérico de 33333 versos-, la palabra literaria de Kazantzakis es honda y esencialmente antidogmática:

No religious dogma, no political ideology may claim Nikos Kazantzakis. His works will always be a heresy to any political or religious faith which exists today or which may be formulated in the future, for in the heart of his spiritual exercises lies a bomb, timed to explode all visions which are betrayed into the petrification of ritual, constitution, or dogma. His works are not solid land where a pilgrim might stake his claim, but the ephemeral stopping stations of a moment where the traveller might catch his breath before he abandons them also, and again strives upward on the steep ascent, leaving behind him the bloody trail of his endeavour ${ }^{4}$.

La relación con España del ilustre escritor y traductor griego fue — como es sabido - especialmente intensa; sin embargo, poco se conoce todavía del largo y atormentado camino de sus obras en plena dictadura franquista, cuando su centelleante pluma tuvo que enfrentarse con la más rígida praxis censoria.

Kazantzakis, eterno y sediento viajero como Ulises, pisó más de una vez tierras espańolas. En el otoño de 1926, durante la dictadura de Primo de Rivera, fue enviado como corresponsal de un periódico griego 5 . En una carta de finales de junio de aquel año, dirigida a la que sería su segunda mujer, Eleni Samios, describía así su forma de prepararse para aquel viaje hacia la tierra de adopción de su inmenso compatricio, Doménikos Theotokópoulos:

Actualmente mi despacho está despejado de libros hebreos y rusos, etcétera y lleno de obras españolas: Don Quijote, Calderón, Lope de Vega, Santa Teresa, Baedecker de España, El Greco, Kultur der

4 Nikos Kazantzakis, Saviors of Gods, trad. Kimon Friar, Nueva York, Simon and Shuster, 1960, p. 39, apud Niki P. Stavrou, op. cit., p. 7. La obra circuló primero en

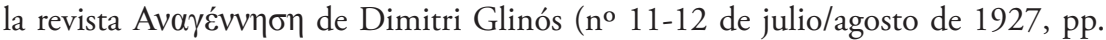

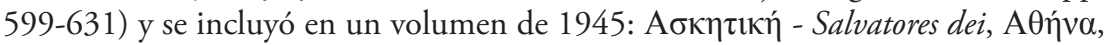
[s.e.], 1945.

5 Los reportajes, 18 en total, fruto de esta estancia se publicaron en el periódico

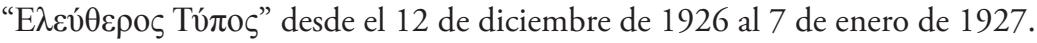


Araber, etcétera [...]. He reunido todos los libros que poseo sobre España, El Greco, etcétera, mi cabeza está ahora llena de España. Quiero acabar con estos países para poder trabajar en paz, sin tentaciones... ${ }^{6}$

En otra epístola del 29 de noviembre de 1926, Kazantzakis aludía a las polémicas surgidas en su patria a raíz de sus reportajes: "Cuando vaya, te hablaré del sobresalto que han causado mis artículos sobre España. Estos artículos han sido considerados por los marxistas ortodoxos peligrosos. Quieren responderme, mantienen conciliábulos, pero algunos de ellos están conmigo» ${ }^{7}$.

El escritor volvería a España en octubre de 1931, durante la Segunda República, y se asentó en la piel de toro hasta marzo de $1933^{8}$. Finalmente, en octubre de 1936, ya en la isla griega de Egina, Kazantzakis recibió del director del periódico griego "H K $\alpha \theta \eta \mu \varepsilon \rho ı \eta ́$ " el encargo de volver

6 Eleni N. Kazantzaki, op. cit., p. 114. Y ańade: "El país tiene un carácter austero, ascético, se aprecia que aquí han nacido los caballeros de la triste figura, muertos por una idea descarnada. Los llanos de Castilla hacen nacer una alucinación [...]. No esperaba esta imagen y soy feliz por comprender mejor así la austera y trágica historia ascética de esta célebre tierra burlada en sus esperanzas" (Ibídem, p. 118). A propósito de Primo de Rivera afirma: "Acabo de ver a Primo de Rivera... Hombre mediocre, animado sin embargo por un soplo superior, el soplo que hoy impulsa a los hombres a organizar con fanatismo la extrema derecha o la extrema izquierda. Trabajo sin descanso. Vago todo el día por los ministerios, estudio las leyes, trato de ver qué se ha hecho en España después de la guerra, en los aspectos de economía, política, comercio, industria, agricultura, ciencias, artes, etcétera... Consulto montones de libros, apenas duermo, estoy poseído de nuevo por la desesperación de llevar hasta el fin la tarea que he acometido" (Ibidem, p. 120).

7 Ibidem, p. 129.

8 El 1 de noviembre de 1932 declaraba en una carta a un joven amigo francés: "Los dos polos opuestos del alma española, Nada y Pasión, me dan el clima austero que me conviene: aquí respiro a gusto. Si pudiera, me instalaría en esta vieja Castilla como si fuese "mi país", El Greco. [...] Contemplar enfrente la Nada, he aquí lo que amo y lo que hallo en la tierra, el aire y los molinos de viento de nuestro Señor Don Quijote" (Ibidem, p. 208).

9 En este periódico se publicaron los reportajes relativos a su estancia española de 1933 (12 artículos del 21 de mayo al 3 de junio de 1933) y también de 1936 (15 artículos desde el 24 de noviembre de 1936 al 17 de enero de 1937). Sobre la relación de Kazantzakis con España y su papel en la Guerra Civil véanse: Lily Litvak 
a España para documentar la Guerra Civil ${ }^{10}$. De sus estancias en tierras españolas nacen las narraciones luego publicadas en los volúmenes de la serie Viajando ${ }^{11}$.

Las décadas de los cuarenta y los cincuenta, cuando salen a la luz sus novelas más famosas, son las que otorgan a Kazantzakis su definitiva y perpetua consagración internacional. Las mismas, en fin, que le llevarían a rozar el premio Nobel (perdido por un voto en 1957). Observando el panorama de las traducciones al castellano de sus obras ${ }^{12}$, nos percatamos de que entre los primeros países que acogieron y difundieron su verbo literario - junto a Suecia y Francia - se hallan también Chile y Argentina $^{13}$, gracias a la labor pionera, por un lado, de las ediciones Ercilla de

de Kravzov, "Nikos Kazantzakis y España", Hispanófila, 29 (enero 1967), pp. $37-$

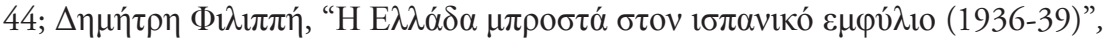
Avií, 23-1-1999, pp. 44-52; véanse también los trabajos incluidos en la sección Nikos Kazantzakis, corresponsal en la Guerra Civil Española, en Letra internacional, 105 (2009), pp. 26-80.

10 Su esposa nos restituye el diálogo entre ambos: “-Sé que hubieras preferido irte con los rojos... Pero te envío con los negros, como los llamas. — ¿Por qué a mí precisamente? - Porque tú dirás la verdad. Tus amigos y tus enemigos te cogerán antipatía y yo estaré encantado con ello. ¿'Te vas inmediatamente o no?” (Ibidem, p. 277). Tres años después, el 20 de febrero de 1939, Kazantzakis, desde Egina, en plenos festejos de carnaval escribe: "Unas máscaras han venido hoy, pero las he despedido diciéndoles que estaba de luto. “QQué luto?”, me han preguntado inquietos, pero no les he dicho que era por España” (Ibidem, p. 297).

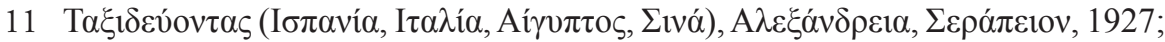

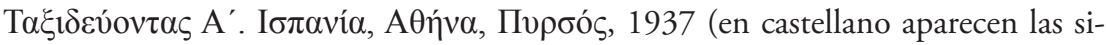
guientes ediciones: Del monte Sinai a la isla de Venus, en Obras Selectas, Barcelona, Planeta, 1962, II; España y Viva la Muerte, traducción del griego de Joaquín Mestre, Madrid, Júcar, 1977; España dos rostros, trad. Joaquín Mestre, Buenos Aires, Carlos Lohlé, 1985; Viajando. España: Viva la Muerte, trad. Guadalupe Flores Liera, Madrid, Ediciones Clásicas, 1988).

12 Un listado actualizado de las traducciones de sus obras está disponible en la página web antes mencionada de las Ediciones Kazantzakis: http://www.kazantzakispublications.org/en/translations3.php.

13 Desde los ańos treinta se publican en Hispanoamérica los siguientes títulos de Kazantzakis: Toda-Raba, trad. del francés por Hernán del Solar, Santiago de Chile, Editorial Ercilla, 1937; El jardin de las rocas, trad. del francés por Luis Alberto Sánchez, Santiago de Chile, Editorial Ercilla, 1938; Cristo de nuevo crucificado, trad. del francés por José Luis de Izquierdo, Buenos Aires, Editorial Carlos Lohlé, 1954; 
Santiago ${ }^{14}$, y por otro, de los editores bonaerenses Peuser y Carlos Lohlé ${ }^{15}$. Si nos desplazamos al panorama peninsular, se nos desvela una geografía editorial algo más tardía y esencialmente dominada por las propuestas

Alexis el Griego, trad. del francés por Roberto Guibourg, Buenos Aires, Editorial Peuser, 1954; Libertad o muerte, trad. del francés por Rosa Chacel, Buenos Aires, Editorial Carlos Lohlé, 1957; Melisa, trad. del francés por Roberto Guibourg, Buenos Aires, Ediciones Losange, 1957 (y Carlos Lohlé, 1957); Teseo, trad. del francés por Luisa Rivaud y Raquel Warschaver, Buenos Aires, Ediciones Losange, 1958; El pobre de Asis, trad. del francés por Enrique Pezzoni, Buenos Aires, Editorial Sur, 1958; La última tentación, trad. del francés por Roberto E. Bixio, Buenos Aires, Ediciones Sur, 1960. A este propósito véase también: Roberto Quiroz Pizarro, "Un escritor griego fuera de Europa”, Byzantion Nea Hellás, 28 (2009), pp. 207-234. Señalamos también que a este mismo estudioso se debe una Cronología y bibliografía castellana de Kazantzakis, publicada como monográfico en Cuadernos Byzantion Nea Hellás, Santiago, Ximpauser, 1997. No he podido sin embargo consultarla.

14 La editorial Ercilla la fundaron Laureano Rodrigo y Luis Figueroa en 1933, en Santiago de Chile. Aquel año empezó a circular también la revista Ercilla. Entre los asesores literarios de la revista y de la editorial aparece el escritor chileno Hernán del Solar, autor de la primera traducción en castellano de una obra de Kazantzakis, Toda-Raba. "Las manos pioneras de los traductores y promotores que se fijaron en un autor poco o nada conocido en la América Hispana, fueron las de Hernán del Solar y Luis Alberto Sánchez. [...] Hernán del Solar Aspillaga (1901-1985) es el nombre del visionario que consideró importante fijarse en la figura de Nikos Kazantzakis —occidentalizado en Francia como Nicolás Kazán— para ser incluido en la tribuna de las letras universales y darlo a conocer. A este chileno le debemos pues la primera traducción de una novela de nuestro autor. Un año después, otro sudamericano, el peruano Luis Alberto Sánchez, traducía El jardín de rocas. Novela de la guerra civil china, a instancias del clima de fronteras abiertas entre las editoriales y sus intelectuales" (Cf. Roberto Quiroz Pizarro, "Un escritor griego fuera de Europa”, p. 215).

15 Véanse Carlos Lohlé, Presencias y experiencias, Buenos Aires, Carlos Lohlé, 1986; y Roberto Quiroz Pizarro, "Un escritor griego fuera de Europa", p. 231, quien alude a la difícil circulación de los libros de Kazantzakis en plena dictadura argentina: "La escritura de Nikos Kazantzakis ha marcado vidas y momentos humanos que pueden ser insospechados. Señalamos un testimonio que nos ofrece el incansable editor holandés, Carlos Lohlé: «En el momento más triste y trágico de la historia argentina recibí de un desconocido, desde la cárcel, una carta suplicándome que le enviara alguna lectura». Pasa el tiempo, y nuevamente, un día cualquiera, Lohlé encuentra otra nota del mismo desconocido: «[...] no sé cómo agradecerle. He leído los libros mandados, y luego los pasé a mis compañeros. Si hemos podido aguantar esta vida atroz, es gracias a los libros de Kazantzakis»" (Ibidem, p. 231). 
editoriales de Planeta, que a partir de 1960 reúne y publica la producción literaria de Kazantzakis en la prestigiosa colección Obras selectas:

- Obras selectas, tomo I, Novelas, Barcelona, Planeta, 1960 Incluye:

Toda-Raba, traducción de Hernán del Solar

Cristo nuevamente crucificado, traducción de José Luis de Izquierdo Hernández

El pobre de Asis, traducción de Enrique Pezzoni

Libertad o muerte, traducción de Rosa Chacel

- Obras selectas, tomo II, Novelas - Teatro - Viajes, Barcelona, Planeta, 1962

Incluye:

El jardin de las rocas, traducción de Enrique de Juan

Vida y hechos de Alexis Zorba, traducción de Roberto Guibourg

Teseo, traducción de Enrique de Juan

Melisa, traducción de María Ángeles Bosch Carbonell

Del Monte Sinai a la Isla de Venus, traducción de Andrés Lupo Canaleta

- Obras selectas, tomo III, Novelas - Teatro - Viajes, Barcelona, Planeta, 1968

Incluye:

Carta al Greco, traducción de Delfín Leocadio Garasa

Los hermanos enemigos, traducción Enrique de Juan

Ascesis, traducción de Enrique de Obregón

Constantino Paleologo, traducción Miguel Castillo Didier

Cristóbal Colón, traducción de Miguel Castillo Didier

Sodoma y Gomorra, traducción de Enrique de Juan

- Obras completas, tomo IV, Barcelona, Planeta, 1975

Incluye:

Odisea, traducción de Miguel Castillo Didier

Sabemos que hubo un primerizo intento de publicar en la España republicana la novela Toda-Raba. En una carta de 1932 al amigo Prevelakis, el escritor alude a la reiterada intención manifestada por Juan Ramón Jiménez de entregar la obra a la editorial Espasa-Calpe para su posible impresión. Afirma, sin embargo, que al poeta andaluz la novela le había 
parecido "exageradamente comunista" 16 . Finalmente, la obra no se publicaría y su primera edición en castellano vería la luz, como se ha dicho, algunos años después: en 1937, en Chile, gracias a las prensas de la editorial Ercilla. A partir de 1975, y hasta nuestros días el panorama se amplía y articula notablemente ${ }^{17}$.

Ahora bien, frente a esta situación, podríamos caer en la tentación de pensar que las obras de Kazantzakis pasaron indemnes por las estrechas mallas de la censura franquista. Y aduciríamos como prueba la presencia de los volúmenes colectáneos de Obras selectas, que la editorial Planeta estampó en plena dictadura. Sin embargo, cotejando la versión que nos brindan estos refinados tomos con las primitivas ediciones 'de bolsillo' argentinas, descubriríamos cómo algunas de sus obras más célebres sufrieron retoques importantes y que las ediciones de las mismas que se imprimieron y circularon durante la dictadura no siempre nos han legado el texto integral.

De hecho, la rigurosa máquina burocrática activada por el Ministerio de Información y Turismo (Dirección General de Información - Sección

16 Y ańade: "Para el pajaro arabo [sic] Toda-Raba es un golpe de cañón" [traducimos

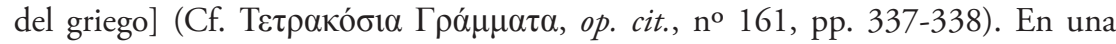
carta anterior, al hablar de Juan Ramón y de su carácter inefable, lo había definido como "un 'poeta lírico'; o sea, un pájaro que trina, pero no se acuerda" (Ibídem, p. 282). En el asunto estaba involucrado también Timoteo Pérez Rubio, pintor y director entonces del Museo Nacional de Arte Moderno de Madrid y marido de Rosa Chacel (que traduciría la novela Libertad o muerte). Ambos, junto a Juan Ramón, intercedieron ante Ortega para la publicación de Toda-Raba en Espasa-Calpe, ya que, al ser la Revista de Occidente "bastante pequeña y totalmente filosófica", resultaba poco probable la inclusión en ella de esta novela (Ibidem, p. 332).

17 Al finalizar la dictadura y durante los años de la Transición, salen a la luz las siguientes ediciones: Cristo de nuevo crucificado, trad. José Luis Izquierdo Hernández, Barcelona, Pomaire, 1976 (Barcelona, Círculo de Lectores, 1977; Madrid, Alianza - Carlos Lohlé, 1984); Cristo nuevamente crucificado - Toda-Raba, trad. José Luis Izquierdo Hernández y Hermán del Solar, Barcelona, Planeta, 1989; España y Viva la Muerte, trad. Joaquín Mestre, Madrid, Júcar, 1977; Viajando. España: Viva la Muerte, trad. Guadalupe Flores Liera, Madrid, Ediciones Clásicas, 1988; La última tentación, trad. Roberto E. Bixio, Madrid, Debate, 1988; El pobre de Asís, trad. Enrique Pezzoni, Madrid, Debate, 1989; Alexis Zorba el Griego, Madrid, Debate, 1990. Para las ediciones sucesivas remitimos a la citada lista de las traducciones y, más específicamente, al catálogo del Sistema Bibliotecario Nacional y al de la Biblioteca Nacional de España. 
Inspección Libros) se enfrentó en diversas ocasiones con las solicitudes avanzadas por editores, importadores y libreros para editar o distribuir en España la obra de Kazantzakis. Según la copiosa e interesantísima documentación relativa a las obras del cretense conservada en el Archivo General de la Administración de Alcalá de Henares (en la sección "Censura literaria”), desde el año 1954 y hasta 1977 — cuando deja definitivamente de aplicarse el mecanismo censorio- se cuentan aproximadamente unos sesenta expedientes relativos a peticiones de importación, distribución y publicación de sus textos. Según apunta Abellán, uno de los alicientes que subyacían a las revisiones puntuales de la censura era, obviamente, la cuestión religiosa:

Curiosamente el tema de la religiosidad o irreligiosidad aparece con una inusitada frecuencia en los informes del año 1960. La autorización del primer tomo de las Obras selectas de Nikos Kazantzaki trae a colación de nuevo el tema, pero [...] esta vez es tratado con benevolencia. Por supuesto N. Kazantzaki no es autor que se proclame antirreligioso. Los censores valoran positivamente que en las obras de este autor el hombre con todos sus defectos y miserias tiende a la perfección unas veces con su Dios, otras alejado de él, pero siempre «buscándole aun sin saberlo» [Nota bene: se trataba de la publicación de Libertad o Muerte, Cristo de nuevo crucificado, El pobre de Asis y Toda Raba]. Las objeciones tanto de orden religioso como políticas algunas, sobre todo en la última de las novelas seleccionadas dejan de ser insalvables por tratarse de una edición de obras selectas, lo cual ya de antemano impide - a juicio de los censores- que la obra caiga en manos de lectores poco formados. Sin embargo, esta voluntad de pereza dogmática por parte de la censura no debe llamar a engaño. Se trata sencillamente de la reacción o respuesta del organismo censor; la naturaleza de ésta — sobre todo su rigor- depende del autor e incluso editor que la provoque. No es tanto, pues, un intento de salvaguardar la pureza moral o dogmática cuanto una manera de represaliar con motivos objetivables a un autor o a una entidad editorial ${ }^{18}$.

18 Manuel L. Abellán, Censura y creación literaria en España (1939-1976), Barcelona, Edicions 62, 1980, pp. 184-185. 
Si bien la mayoría de estos expedientes alcanzaron la autorización solicitada y sin excesiva demora, en algunos casos — que aquí analizaremos con detalle- el iter fue algo más complejo. Es lo que ocurrió, por ejemplo, con la más célebre novela de Kazantzakis, Vida y hechos de Alexis Zorba, que el autor publicó en $1946^{19}$ y en la que describe las 'hazañas' y la filosofía vitalista de un moderno y genuino héroe-pícaro: George Zorba ${ }^{20}$.

La odisea editorial española de la obra empieza en 1955 - y quizás no casualmente un 25 de marzo (fiesta nacional en Grecia, como recuerdo de la efeméride de la victoriosa revolución de 1821 contra la dominación otomana)_-, cuando a la Dirección General de Información llega una solicitud para autorizar la importación del libro Alexis el griego, publicado en Buenos Aires por los talleres de Peuser el año anterior. En la papeleta azul que acompaña todo expediente de censura literaria (sintetizando puntualmente su iter), se indica que la lectura del texto fue confiada a los lectores $n^{\circ} 7$ y no 26 , con fecha 4 de abril de $1955^{21}$. La resolución defini-

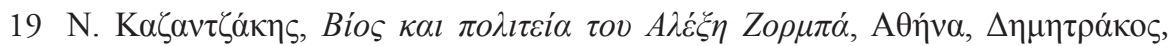
1946; traducido el año siguiente al francés (París, Éditions du Chêne).

20 El escritor conocía muy bien a Zorba, con el cual, en 1919, siendo Ministro de Asistencia Pública, emprendió la difícil misión de repatriar unos ciento cincuenta mil refugiados griegos desde el Cáucaso. Sobre la amistad entre ambos, véase

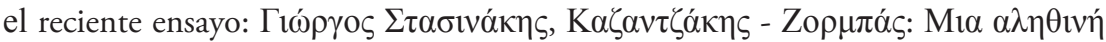

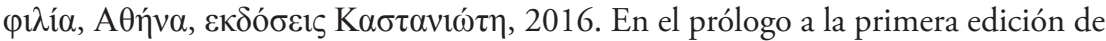
la novela, el autor escribía: "A menudo he querido narrar los hechos y hazañas de Alexis Zorba, un viejo jornalero al que he querido mucho. En el curso de la vida, mis mayores benefactores han sido los viajes y los sueños. Los hombres, muertos o vivos, me han ayudado poco en mi lucha. Sin embargo, si yo quisiera distinguir a los hombres que han dejado una huella más profunda en mi alma, quizás me decidiera por Homero, Buda, Bergson, Nietzsche y Zorba. [...] Hagamos todo lo que podamos para que viva siquiera un poco este maravilloso bebedor, comilón, trabajador, mujeriego y vagabundo. El alma más grande, el cuerpo más firme, el grito más libre que he conocido en mi vida" (cf. N. Kazantzakis, Zorba el griego, introducción inédita del autor, Barcelona, Círculo de Lectores, 1986 [Buenos Aires, Carlos Lohlé, 1973], pp. 7 y 11). La mitificación definitiva de Zorba se debe asimismo a la magistral interpretación de Anthony Quinn en la homónima película dirigida por Michael Cacoyannis en 1964, cuya famosísima banda sonora fue compuesta por el maestro Mikis Theodorakis.

21 Archivo General de la Administración (AGA), caja 21/11049, expediente no 1795/55. En este expediente faltan, sin embargo, los informes de los lectores. 
tiva, firmada el 18 de abril de aquel mismo año por el Director General, decreta la suspensión de dicha importación.

Algunos años más tarde, vuelve a activarse la operación: el responsable de la Sociedad General Española de Librería S.A. de Madrid solicita, el 30 de octubre de 1958, la autorización para la importación de la edición francesa de la novela Alexis Zorba, publicada por la editorial Plon de París $^{22}$. En el informe, cumplimentado esta vez por el lector no 3, con fecha de 6 de noviembre de 1958, se leen las siguientes observaciones:

La acción de este libro se desarrolla en Creta, donde Zorba dirige los trabajos en una mina de carbón. Zorba es el prototipo de una caballerosidad primitiva: honesto, filósofo, creyendo en un orden personal del universo, batallador y mujeriego. El libro gira alrededor de sus gestas cotidianas, que ponen en evidencia su manera de actuar y de pensar ante la vida. Aparecen en el libro las costumbres primitivas y salvajes de la aldea cretense y unos monjes, poco edificadores, de un convento de rito oriental. PUEDE AUTORIZARSE LA IMPORTACIÓN ${ }^{23}$.

La autorización fue efectivamente concedida el 11 de noviembre. En este caso, al tratarse de un texto en lengua extranjera, al que accedería con toda evidencia una minoría de lectores, su entrada en Espańa fue tolera$\mathrm{da}^{24}$. Tal actitud permisiva no volvió a darse al año siguiente, en 1959, cuando la editorial Planeta, por medio de su responsable editorial, Santiago Galán Conde, quiso solicitar la publicación en castellano de la novela (en el volumen 349 de la colección Literatura, con una tirada prevista de dos mil ejemplares y al precio de cien pesetas). En dicho expediente, que

22 AGA, caja 21/12181, expediente no 4990/58.

23 En la transcripción de los informes se mantienen las palabras o frases en letra mayúscula o subrayadas, tal como aparecen en la documentación original. Nos limitamos tan solo a integrar la acentuación donde falte.

24 A este propósito las posibles objeciones a la publicación tenían en cuenta las modalidades de su circulación, y podían hacerse más tolerantes si se trataba de ediciones colectivas y de cierto prestigio, como lo son los tomos de las Obras Selectas, "lo cual ya de antemano impide - a juicio de los censores - que la obra caiga en manos de lectores poco formados". Remito a Manuel L. Abellán, op. cit., p. 185. 
incluye toda la documentación relativa al proceso editorial ${ }^{25}$, constan tres solicitudes del editor. Una primera, fechada a 28 de noviembre de 1959, en la que se apunta en rojo la resolución final: "Denegada 4-1-60". Una segunda solicitud, del 3 de septiembre de 1960, con asunto "Revisión de la obra”, en la que el editor

SOLICITA sea leída nuevamente la obra "Alexis el griego" de Nikos Kazantzaki, que fue suspendida por su oficio el 4 de enero de 1960, notificando respecto de la misma que no será publicada por separado, sino en tomo encuadernado en piel, siendo de 450 pesetas el precio del ejemplar, lo que hará más difícil su difusión, estando dispuestos a corregir o suprimir todos los párrafos o episodios que juzguen convenientes, para poder obtener así la tarjeta de autorización definitiva ${ }^{26}$.

Como se puede apreciar de la diplomática, si bien firme, captatio benevolentice de Santiago Galán Conde —en aparente contradicción con la política comercial de cualquier editor- el coste mismo del tomo encuadernado en piel sería una justificación suficiente para la circulación limitada de la obra, cuyo mensaje repercutiría entonces sobre un número bastante reducido de lectores. Como aclara Abellán,

el editor o el director literario de una empresa editora se encuentra en la difícil situación de ser juez y parte al mismo tiempo. Tiene que

25 AGA, caja 21/12601, expediente no 6148/59. En la misma caja se recoge el expediente relativo a la publicación de la novela Toda-Raba (n ${ }^{\circ}$ 6147/59). El editor de Planeta envió la solicitud el 28-11-59 y el informe lo hace el Lector no 11 , que firma este juicio conclusivo: "Se trata de una novela sumamente extraña que es ante todo una descripción de tipos y de régimen: el comunista. De todas las partes del mundo van acudiendo a Moscou para un convenio del partido comunista: un negro, un chino americano, un derviche, un indio... Con este motivo se [palabra ilegible] la dureza, la miseria, la amargura, el despejamiento del bolcheviquismo. PUEDE PUBLICARSE, Madrid, 25 de diciembre de 1959”. La publicación de Toda-Raba fue definitivamente autorizada el 13 de enero de 1960.

26 Esta última frase aparece subrayada con lápiz azul y acompañada de la indicación: "L 24 24-XI-60". Al margen aparece escrito "Revisión" y por debajo se lee: "visto informe de Asesor Religioso, se propone la autorización en revisión con supresiones en las págs: 134-135-154-222-223-224-225-228-229-245-318. 1-XII-60”. 
juzgar una obra por sus cualidades artísticas o literarias, pero sin perder de vista tampoco las consecuencias económicas que se derivarían de una publicación cuyo acceso al consumo legal implique, a los ojos de la institución censoria, complicidad en la difusión de materias delictivas ${ }^{27}$.

En este sentido, el papel en la difusión de la obra de Kazantzakis por parte de la editorial Planeta — con Nadal una de las más importantes de Espańa - resultó fundamental, ya que apostó por el valor artístico de la misma, enmarcándola en un proyecto de veras ambicioso.

La tercera solicitud del editor, enviada el 24 de marzo de 1962, lleva por asunto: "GALERADAS CORREGIDAS de la obra "Alexis el Griego" por Nikos Kazantzaki”. En este documento, el editor vuelve a insistir para que el Director General,

una vez comprobadas las GALERADAS ADJUNTAS de la obra: "ALEXIS EL GRIEGO", de Nikos Kazantzaki, en las que se han hecho las correcciones indicadas en su oficio del 1 de diciembre de 1960, páginas 134, 135, 154, 222, 223, 224, 225, 228, 229, 236, 243 y 318, a las que corresponden las páginas 76, 87, 127, 129, 133, 137 y 181 de las Galeradas adjuntas, se digne autorizar dicha obra, concediendo Tarjeta de Autorización definitiva ${ }^{28}$.

A las tres solicitudes corresponden, obviamente, tres informes distintos. El primer informe, de $1^{\circ}$ de diciembre de 1959, remite al expediente 1795-55 (anteriormente citado) y a la consiguiente suspensión (18 de abril de 1955) de la importación de la edición bonaerense. Está redactado por el lector $n^{\circ} 5$, que anota el siguiente juicio:

"Alexis el griego" es una gran novela cuya sustancia se reduce a presentar el autor un tipo de hombre, Alexis Zorba, que trabaja para un patrón explotando una mina. Zorba es personaje interesante y lleno de matices originales. El patrón le lleva a Creta, donde se trabaja la mina. La novela discurre por un cauce limitado a diálogos y conversaciones entre el patrón y Zorba, que si llenos de áspera

27 Cf. Manuel L. Abellán, op. cit., p. 97.

$28 \mathrm{Al}$ margen de la solicitud se lee, apuntado en lápiz azul: "Autorizado 27-III-62". 
originalidad están constantemente entreverados de licencias de expresión, ya referentes a la divinidad, con jocosidades y chocarrerías, ya derivando también a inconveniencias sobre el sexo y la mujer. En los primeros aspectos se pone a veces en duda la existencia de Dios. Por ejemplo: "Y si Dios existe, peor que peor; fastidiados estamos". Otras veces: "si hubiera de creer en el hombre, creería también en Dios". Expresiones de esta clase tejen toda la novela. En otras ocasiones, como apuntamos, hácese referencia a carnalidades con expresiones como estas: "felices los muslos que la aprietan". Et sic de caeteris. Por lo que estimamos QUE NO SE DEBE IMPORTARSE NI EDITARSE.

El informe lleva fecha del 19 de diciembre de 1959 y la firma legible del lector: se trata del padre agustino Miguel de la Pinta Llorente ${ }^{29}$. Unos días después, el 4 de enero de 1960 la Dirección General de Información rechazaba la autorización a la publicación, como rezaba — según se ha anticipado antes - en la primera solicitud del editor de Planeta.

El segundo informe, recogido en el expediente no $6148 / 59$, se redactó el 22 de noviembre de 1960, a consecuencia de la solicitud de revisión antes citada, avanzada por el editor con fecha 3 de septiembre de 1960. Esta vez la Dirección General encargaría la tarea al lector no 24 , el padre Saturnino Álvarez Turienzo ${ }^{30}$, que el 28 de noviembre de dicho año firma el siguiente y menos adverso juicio:

Un griego inquieto e idealista, en camino hacia la isla de Creta para explotar una mina, se encuentra con un extrańo personaje, vagabundo de profesión, experimentado y desengañado de casi todas las cosas... Este sujeto siembra de sus opiniones las páginas, frecuentemente lleno de desenvoltura. Como sus críticas intemperantes alcanzan a todo lo humano y lo divino, resulta a veces su lenguaje demasiado negativo. No obstante, ciertas circunstancias del relato disculpan los atrevimientos, que de hecho son menos demoledores de lo que indica a veces la letra. El libro es, por otra parte, un ma-

29 Historiador y autor de ensayos sobre la Inquisición y la ortodoxia católica, como La Inquisición española, Madrid, Archivo Agustiniano, 1948; y Aspectos históricos del sentimiento religioso en España. Ortodoxia y Heterodoxia, Madrid, CSIC, 1961.

30 Religioso agustino y catedrático de ética en la Universidad Pontificia de Salamanca. 
nifiesto de exaltación a la verdadera amistad. Suprimiendo los tachados de las páginas: 134-135, 154, 222-225, 228-229, 245, 318, PUEDE AUTORIZARSE ${ }^{31}$.

En la sección "Recursos” de dicho informe, firmada en Madrid dos años después, el 2 de abril de 1962, se lee:

En el plazo reglamentario se interpone RECURSO DE REPOSICIÓN; una vez comprobadas las correcciones ordenadas por la Superioridad, se propone su autorización en revisión. Madrid, 2 de abril 1962 EL JEFE DEL LECTORADO. / VISTOS los fundamentos alegados y el nuevo informe, se declara concluso el expediente modificando la anterior resolución AUTORIZANDO EN REVISIÓN. Adquiriendo carácter firme la resolución.

El expediente, junto a los informes y a las solicitudes del editor, comprende también un ejemplar de la quinta edición bonaerense ${ }^{32}$, en cuya portada se halla pegada una hoja con la siguiente indicación: "Suprímase lo indicado en las páginas, 134, 135, 154, 222, 223, 224, 225, 228, 229, 243, 318 y preséntese galerada impresa”. En dichas páginas del ejemplar figuran unos párrafos enmarcados y tachados con lápiz rojo, que corresponden a las partes que había que suprimir para que pudiera publicarse. Consideramos oportuno transcribir de forma integral todas las partes tachadas $^{33}$, para que quede más nítido el tono de las mismas. La primera intervención censoria remite a un pasaje en el que la vis comica de Zorba sobrepone al plano erótico-sensual el religioso-espiritual, justificando de esta forma las pulsiones de la carne:

Cap. X, pp. 134-135:

“-Bien está — dijo con fastidio—. ‘ ¡Vamos! Pero quiero que sepas que más le agradaría a Dios que hubieras visitado esta noche a la viuda, como el arcángel Gabriel. Si Dios hubiera emprendido el

31 En el margen de este informe, aparece la siguiente frase: "Comprobadas y controladas las tachaduras. 27-3-62".

32 Niko Kazantzakis, Alexis el griego, trad. del francés por Roberto Guibourg, Ediciones Peuser, Buenos Aires, 1958 ( $5^{\mathrm{a}} \mathrm{ed}$.).

33 Transcribimos a partir de la cuarta edición argentina (Peuser, 1955). 
mismo camino que tú sigues, patrón, Jesús no hubiera nacido. Y si me preguntas cuál es el camino de Dios, te diré que es el que conduce hacia María. María para ti es la viuda...”.

No estamos, en verdad, muy lejos de la pragmática y socarrona pedagogía educativa del gracioso respecto a su amo en el teatro del Siglo de Oro. El segundo fragmento censurado evidencia el materialismo y la falta de auténtico espíritu religioso en un clérigo ortodoxo, más inclinado a los apetitos de la carne que a los que impone la solemnidad litúrgica de la Eucaristía navideña:

Cap. X, p. 135:

"El pope Stéfano, alto, exacerbado por el ayuno de cuarenta días, revestido de la densa casulla de oro, corría de aquí para allá, a largas zancadas, agitando el incensario, cantando a voz en grito, con la prisa de que naciera el Niño para volver a su casa y arrojarse sobre la sopa gorda, los salchichones y las carnes ahumadas...”. [...] Los labradores se dirigían apresuradamente a sus casas hambrientos, felices, para refocilarse en la tradicional francachela " $y$ sentir hasta en lo más hondo de sus vientres el misterio de la encarnación. El vientre es base sólida: pan, vino, carne, ante todo; sólo con pan, vino y carne puede crearse a Dios".

En el cap. XI, p. 154, de la novela se lee otra frase potencialmente peligrosa para el equilibrio puritano de un español medio de la época: “¡Cómo me gusta tu cuerpo, hermoso, vibrante y fuerte, que acoge viva a la anguila, y al punto la vuelve inerte!”. Una intervención de calado es la que deja en el tintero un episodio de tres páginas en el que se describen las actitudes lascivas y la malicia de unos monjes — con alusiones implícitas a su homosexualidad_-, amén de la consiguiente y rotunda repulsa de Zorba. He aquí el pasaje:

Cap. XVII, pp. 222-225:

"Pero el gordo Dometios me observaba con el belfo colgante como el de un cabrón, y esperaba impaciente.

-Tengo ganas de romperla para ver... No puedo conciliar el sueño a causa de esta duda. ¿Si guardara allí algún diamante?

Yo miraba a la graciosa jovenzuela de tetas erguidas, desterrada 
en este lugar extraño, entre humo de incienso y dioses crucificados que abominan de la carne, de la risa, del beso. '¡Ah, si me fuera dado salvarla!'.

Zorba tomó la estatuilla de barro, palpó el menudo cuerpo de mujer, deteniendo los dedos temblorosos en los pechos firmes y erectos.

— ¿Acaso no adviertes, monje — dijo-, que éste es el diablo? Es el mismísimo diablo en persona, no hay duda posible. ¿Si lo conoceré yo al maldito! Mírale el pecho, padre Dometios, redondo, firme, fresco. ¡Así es el pecho del diablo, yo te lo aseguro porque lo sé muy bien!

La figura de un monje joven se dibujó en la puerta. El sol le alumbró los dorados cabellos y el rostro ovalado de fino vello.

El monje de lengua viperina guiñó un ojo al padre hospedador. Ambos sonrieron maliciosamente.

—Padre Dometios — dijeron—, tu novicio, Gavrili.

El padre se apoderó al instante de la mujercilla de barro y se dirigió rodando como un tonel hacia la puerta. El hermoso novicio marchaba adelante, en silencio, contoneándose, Desaparecieron ambos en el largo corredor desmantelado.

Con un ademán le indiqué a Zorba que saliéramos al patio. Hacía calor. En medio del patio un naranjo en flor perfumaba el aire. Junto a él, de una antigua cabeza de carnero esculpida en mármol manaba agua murmullante. Puse la cabeza bajo el chorro y me refresqué.

—Dime, ¿qué bichos son estos? — preguntó Zorba con gesto de asco- Ni hombres, ni mujeres. ¡Mulos! ¡Puah! ¡Ojalá los cuelguen a todos!

Metió la cabeza también él en el agua fresca y se echó a reír.

—iQue los cuelguen! —repitió-. Todos llevan un demonio consigo. Uno quiere una mujer; otro, bacalao; otro dinero; el de más allá, periódicos y política... ¡Cáfila de bestias! ¿Por qué no se mezclarán de una vez con la gente, para hartarse de todo y purgar el cerebro?

Encendió un cigarrillo y se sentó en un banco al pie del naranjo en flor.

-Cuando yo deseo algo ¿sabes qué hago? Me lleno hasta el gaznate, para librarme de toda obsesión y no pensar ya en ello. O si me da por recordarlo, será con náuseas. Una vez, siendo pequeñito, me 
entró la locura de las cerezas. No tenía dinero, las compraba de a puñaditos por vez, de modo que cuando las había comido me quedaba con ganas de seguir comiendo. Noche y día no pensaba en otra cosa, se me caían las babas, ¡un verdadero tormento! Pero un día me enojé, o me avergonzó la incapacidad de satisfacer el deseo; comprendí que las cerezas me dominaban ignominiosamente, hasta el extremo de que me sentía grotesco. ¿Qué hice, entonces? Me levanté durante la noche; a paso de lobo entré en la alcoba de mis padres, rebusqué en los bolsillos, encontré en ellos un medjidié de plata, y a la mañana siguiente, muy tempranito, le compré a un hortelano un cesto de cerezas. me senté al borde del camino y empecé a engullir cerezas y continué tragando cerezas hasta que se me hinchó el vientre. El estómago no aguantó el atracón, y vomité. Vomité, patrón, las entrañas. Pues desde ese día, se acabaron para mí las cerezas; no las podía ver ni en pintura. De igual modo procedí más tarde con el vino, y lo mismo con el tabaco. Bebo y fumo todavía; pero en cuanto me lo propongo ¡zas! corto. No me domina la pasión. Cosa semejante me ocurrió con la patria. Deseé servirla; la serví hasta asquearme, vomité y me libré de la pasión patriotera.

- ¿Y con las mujeres, Zorba? -le pregunté-.

— ¡Ya les llegará la vez, a las condenadas! ¡Ya les llegará! Pero cuando tenga yo setenta ańos.

Meditó un instante: le pareció breve el plazo.

— ¡Pongamos ochenta! — corrigió- Te causa risa, patrón; ríete, si quieres. Sin embargo, oye lo que te digo: solamente así se libera el hombre, hartándose de todo; no haciéndose ermitaño. ¿Cómo quieres, viejo, expulsar de ti al diablo, si no eres tú diablo y medio?

Resoplando apareció Dometios en el patio, seguido del monjecito rubio.

—Parece un ángel irritado — murmuró Zorba, que admiraba el aspecto silvestre y la gracia natural del efebo-.

Se acercaron a la escalera de piedra que lleva a las celdas del piso superior. Dometios le dijo algo al monjecillo. Este sacudió la cabeza como negándose. Pero al instante se inclinó, sumiso. Apoyó el brazo en la cintura del viejo, y ambos subieron lentamente la escalera.

— ¿Viste? —me preguntó Zorba-. ¡Sodoma y Gomorra!

Dos monjes asomaron el hocico, se dirigieron recíprocos guiños, murmuraron unas palabras y se rieron a coro.

—iQué perversidad! — comentó gruñendo Zorba—. Los lobos 
no se comen entre sí, pero los monjes lo hacen. Mira cómo se muerden uno a otra.

—Uno a otro — corregí riendo-.

-Viejo, aquí tanto da, no te atormentes. ¡Mulos, te digo, patrón! Puedes decir a tu antojo, Gavrili o Gavrila, Dometios o Dometias, Vayámonos, patrón; firmemos cuanto antes los papeles y marchémonos. A fe mía que aquí te asqueas a la vez del hombre y de la mujer".

Otros dos pasajes tachados responden una vez más a la combinación, y por ende a la confusión, entre los niveles religioso y profano, considerada inoportuna en la medida en que el 'catecismo burlesco' de Zorba implica una ridiculización del ámbito dogmático y teológico:

Cap. XVIII, pp. 228-229:

“Por eso! Porque Lola me ha devorado, es decir, te ha devorado no poco dinero. ¿Pensaste que yo lo había echado en olvido? Uno tiene su amor propio, ¿o qué crees tú? ¡Mi reputación debe quedar inmaculada! He gastado, pago. Ya tengo las cuentas bien hechas: Lola nos costó siete mil dracmas; pues las descontaré del valor del bosque. El Higumeno, el monasterio, la Virgen, pagarán por Lola. Ese es mi plan, ¿no te agrada?

—En modo alguno. ¿Por qué la Virgen habría de cargar con tus derroches?

-Porque es responsable y más que responsable. Ella dio vida a su hijo; su hijo me dio vida a mí, Zorba, y me ha dotado de los instrumentos que sabes. Y por obra de estos malditos instrumentos, dondequiera que me encuentre con la especie hembra tengo que perder la cabeza y abrir la bolsa. Así pues, que cada cual pague sus deudas".

Cap. XXV, p. 318:

“-Es obra de importancia — les decía—. Y difícil: hay que hallar la pendiente exacta ¡toda una ciencia! para lo cual me estrujé los sesos durante meses sin resultado. Para los trabajos de gran alcance, no basta la inteligencia del hombre; es menester que la ilumine el aliento de Dios. Así pues, viendo lo que yo penaba, la Santísima Virgen se compadeció y dijo: - Este pobre Zorba es un buen tipo; lo que realiza es en beneficio de la aldea; ayudémoslo un poquillo...Y, ¡oh, milagro...! 
Zorba se interrumpió, persignose tres veces y continuó luego:

¡Oh, milagros! Una noche se me presentó en sueños una mujer vestida de negro: era Nuestra Señora. Llevaba en la mano un minúsculo transportador aéreo, no mayor que esto. Zorba, me dijo, del cielo te traigo el proyecto realizado. Toma, ponle esta inclinación al cable y sea contigo mi bendición. Dicho lo cual desapareció de pronto. Entonces desperté sobresaltado; corrí hacia el lugar en que ensayaba mi invento ¿y qué veo allí? ¡Pues que el hilo había tomado por sí la inclinación exacta y olía aún a benjuí, lo que prueba que la Virgen lo había tenido en sus manos!”

Ahora bien, resulta evidente que en todos estos pasajes el leit motif que impulsa la reacción censoria es la entrega del protagonista a una sensualidad de marcado tono anticlerical y — diríamos hoy-politically incorrect. Sin embargo, hay que notar que las primerizas anotaciones del padre Miguel de la Pinta Llorente, ejemplificadas en unas pocas frases de corte blasfemo o lascivo ${ }^{34}$, no vuelven a reiterarse en esta segunda revisión, en el haber del padre Álvarez Turienzo, cuya pluma privilegia la eliminación de los sobredichos pasajes.

Entre las supresiones sugeridas por el censor estaban incluidos también otros dos períodos de la narración que, sin embargo, finalmente no se enmiendan, manteniéndose en la edición definitiva de la obra publicada por Planeta. Se trata de dos mordaces afirmaciones anticlericales del 'gracioso' Zorba:

Cap. XVIII, p. 236:

“_ ¡Canallas! ¡Crápulas! — dijo escupiendo hacia el monje fugitivo- ¡Popes, monjes, monjas, sacristanes, yo escupo en vosotros! y escupo en vosotros!"35

Cap. XIX, p. 243:

“- Todo lo bueno que se encuentra en el mundo ¿̨no lo has ob-

34 Véase el informe del 19 de diciembre de 1959, arriba transcrito (véanse pp. 10-11).

35 Este parlamento de Zorba aparece tachado en rojo y luego enmarcado con lápiz azul, como la siguiente cita de la p. 243. En las galeradas de la edición de Planeta este parlamento se conserva y, de hecho, en la hoja pegada a la portada de la edición bonaerense la p. 236 no se halla entre las que hay que enmendar. 
servado, patrón? Es invento del diablo: las mujeres bonitas, la primavera, el lechoncito asado, el vino, todo obra del diablo. Y Dios ha creado a los monjes, al ayuno, a las mujeres feas ipuah!"36

En el expediente se hallan también las galeradas de la edición de Planeta con las supresiones puntualmente señaladas ${ }^{37}$. A raíz de estas enmiendas, la Dirección General de Información autoriza finalmente, con fecha 2 de abril de 1962, la publicación de la novela, que se incluye —expurgada de los sobredichos pasajes - aquel mismo año en el segundo tomo de las Obras selectas.

El texto seguiría conservando estas mismas intervenciones no sólo, como es obvio, en las sucesivas reediciones de las Obras selectas, sino también en la edición que con el título Vida y hechos de Alexis Zorba la misma editorial Planeta volvió a publicar aislada en $1977^{38}$. Habrá que esperar hasta los ańos ochenta para volver a disfrutar la versión integral, recuperada a través de la edición argentina de Carlos Lohlé39.

Podemos ańadir otra pieza al complejo mosaico relativo a la novela que mitifica a Zorba acudiendo nuevamente a la documentación conservada en el Archivo General de la Administración, que nos brinda otro expediente a raíz de la solicitud enviada, el 23 de junio de 1965, a la Dirección General de Información por la Editorial Vergara de Barcelona para una

36 Este párrafo de la p. 243, a pesar de incluirse en la sobredicha hoja junto con las demás enmiendas por hacer, finalmente no se eliminó.

37 "Supresiones que se han efectuado en el original y que corresponden a las siguientes compaginadas: Original: 134-135, 154, 222-223-224-225, 228-229, 236, 243 , 318 > Galerada: 76, 87, 127, 129, 133, 137, 181”. Como ya he indicado en las dos notas precedentes, los párrafos de las páginas 236 y 243 de la edición bonaerense no se suprimen y, curiosamente, nadie se entera de su presencia.

38 En el AGA se conservan también los expedientes relativos a la cuarta edición de Obras selectas de 1974 (caja 73/04552, expediente 13420) y a la primera edición en la Colección Popular mayor de 1977 (caja 73/06139, expediente 6556).

39 N. Kazantzakis, Alexis Zorba el griego, Madrid, Alianza, 1985; N. Kazantzakis, Zorba el griego, introducción inédita del autor, ilustraciones de Eduardo Arranz-Bravo, reflexión sobre la novela y el cine de Terenci Moix, semblanza biográfica de Helen N. Kazantzakis, Barcelona, Círculo de Lectores, 1986; N. Kazantzakis, Alexis Zorba el griego, Madrid, Editorial Debate, 1990. Las tres ediciones siguen la versión publicada en Buenos Ares en 1973, especificando que la licencia editorial se concede por cortesía de Carlos Lohlé. 
tirada en catalán de 2.000 ejemplares de Alexis $Z o r b a^{40}$. En el informe se indican los antecedentes (4990-58 Aut. P.B.). En el espacio reservado al número del Lector que debía revisar la obra, aparece primero el no 27, luego tachado y sustituido por el no 13 , acompañado por la fecha (7-71965). En las observaciones dicho lector apunta:

Esta novela de tipo en cierto modo parecido al de nuestra picaresca, gira en torno a un protagonista que hizo de todo en la vida y cuyo carácter alegre se manifiesta sobre todo en su afán de gozar de la vida y de las mujeres. Es una mezcla de descreído y volteriano que se burla de los monjes griegos y a veces con cierta donosura. Puede autorizarse, sobre todo si se tiene en cuenta que ya se autorizó en castellano. Madrid, 16 de julio de 1965.

La autorización final se concede el 19 de julio de 1965, sin que se sugiera ni opere ningún tipo de supresión. Es posible que sobre este juicio positivo pesara la consideración de la relativa fruibilidad de la obra, considerada la minoría de lectores ${ }^{41}$.

Además de Vida y hechos de Alexis Zorba, otros títulos de Kazantzakis tuvieron que someterse a la atenta lectura y solícita intervención de la censura. Es el caso, por ejemplo, de las novelas Cristo de nuevo crucifi-

40 AGA, caja 21/16376, expediente no 4740-65. En catalán se había publicado también la novela El Crist de nou crucificat (traducción de Joan Sales, Barcelona, Club del Editor, 1959).

41 En el prólogo a la edición, que saldría a luz en 1965, el traductor Jaume Berenguer Amenós, que utiliza la edición francesa de Plon y la bonaerense de Lohlé, afirma: «En aquestes versions observem moltes negligències: s'hi escurcen, resumeixen o treuen paràgrafs sencers, i no són rares les equivocades interpretacions de mots i frases; a l'edició hispano-americana fins i tot n'hi ha alguna d'originada per errades d'impremta de la francesa» (p. 18), apud Joaquim Gestí Bautista, Traduccions catalanes de literatura neogrega, Tesis doctoral dirigida por Montserrat Bacardi, Universitat Autònoma de Barcelona, Facultat De Traducció I D'interpretació, Doctorat En Traducció I Estudis Interculturals, Bellaterra, 2015, p. 242. 
cado $^{42}$ y Libertad o muerte $e^{43}$, o del reportaje Del monte Sinai a la isla de Venus, una sección del cual está dedicada a España ${ }^{44}$.

Por lo que se refiere a las dos novelas, el proceso fue, en todo caso, menos borrascoso. En mayo de 1954 el librero barcelonés José Casajuana Llonch solicitaba a la Dirección General de Información la autorización para la importación de mil ejemplares de la edición bonaerense de Carlos Lohlé de la novela Cristo de nuevo crucificado ${ }^{45}$. A tal petición le siguió el correspondiente informe, redactado el 28 de junio de 1954 por el Lector no 28 (José Blat) ${ }^{46}$, quien anota el siguiente juicio mecanografiado:

La acción de la obra se desarrolla en una aldea griega sometida al protectorado turco, y gira en torno de la dramática pugna planteada entre los nativos y un grupo nutrido de personas desplazadas, también de nacionalidad griega, que a todo trance necesitan disponer de tierras para sustento. La lucha, llena de simbolismos y evocaciones de la vida de Jesucristo, alcanza caracteres épicos y termina con una matanza general entre los dos bandos. Añade un profundo interés a la obra el hecho de que sus personajes más destacados intervienen en la escenificación de la Pasión, tradicional en aquel medio, observando una similitud de vida, descrita con extraordinario acierto, la persona real y la figurada. En resumen: es una novela de belleza excepcional y de fondo profundamente religioso, aunque

42 Obra escrita en 1948. Su primera edición sale en traducción sueca (Livets oppstan-

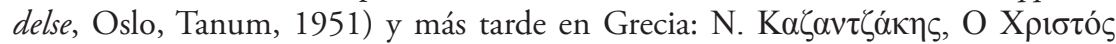

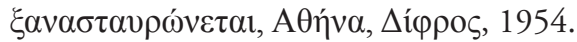

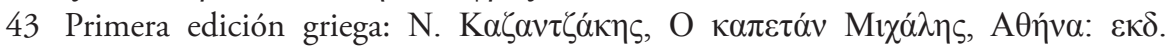
Mavpíó 1953. El mismo año apareció también la primera traducción en finlandés (Vapaus tai Kuolema, Tamni, Kustannusokeylitio, 1953).

44 Estos cuadernos de viaje incluyen siete capítulos dedicados a las impresiones suscitadas en Kazantzakis entre 1927 y 1937 por el mundo oriental (el Monte Sinaí, Panaït Istrati encuentra a Gorki, Japón, China) y las culturas occidentales (España, Shakespeare y Grecia). El capítulo sobre España, el V, reúne y sintetiza impresiones de Ávila, Toledo, Córdoba, Granada y Salamanca, tomadas alternativamente de las dos

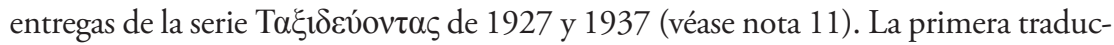
ción apareció en París, gracias a los talleres de Plon, en 1958. A partir de esta versión francesa, Andrés Lupo Canaleta acometió su propia traducción al castellano.

45 AGA, caja 21/10753, expediente no 3599/54.

46 Fue autor de varios ensayos sobre la educación y funcionario ministerial durante los sesenta (participó en la redacción del Libro Blanco en 1969). 
pueda parecer inoportuna la identificación que establece, entre los bolcheviques y el bando oprimido, el bando opresor (véanse pag. 325-326 y 327). Es innecesario y debe suprimirse en cambio, lo acotado en la pag. 441. PUEDE PUBLICARSE.

En el margen del informe figuran dos anotaciones sucesivas. La primera reza: "NO TIENEN INCONVENIENTE LAS SUSPENSIONES INDICADAS. PUEDE PUBLICARSE. 21-7-54”. La segunda solicita la revisión por parte de un censor eclesiástico: "Que el C.E. vise las págs. que indica el lector, teniendo en cuenta es obra de importación. 2-7-54”. La importación de la obra se autoriza, sin mayores intervenciones, el 22 de julio de 1954.

Por lo que atañe a la llegada a España de Libertad o muerte (Buenos Aires, Carlos Lohlé), solicitada el 7 de noviembre de 1957 por el importador DELSA Francisco Salvado Domingo, esta se concluye positivamente el 29 de noviembre del mismo año, previo paso por la censura ${ }^{47}$. El encargado de revisarla es el Lector no 10 (Gonzalo Gómez-Acebo de Carlos), quien cumplimenta de este modo la primera sección del informe:

¿Ataca al dogma? Sí páginas 11/291

¿A la moral? SÍ páginas 14/30/45/89/108/153/286/288/290

$¿ A$ la Iglesia o a sus Ministros? NO

¿Al Régimen y a sus instituciones? NO $\mathrm{NO}$

¿A las personas que colaboran o han colaborado con el Régimen?

Los pasajes censurables ¿califican el contenido total de la obra? NO; se trata de una novela áspera realista, cruda, pero en modo alguno tendenciosa ni morbosa.

Informe y otras observaciones:

Tanto las faltas al dogma cómo las señaladas contra la Moral, son consecuencia de un planteamiento descarnado de la obra; en ella la protagonista es Creta, y lo mismo las luchas que los abrazos sexuales de sus personajes, son únicamente detalles, necesarios para fijar en el ánimo del lector la rudeza del clima moral y físico; puede la obra ser peligrosa para imaginaciones jóvenes y excitables; en todo caso estimo que el autor no ha pretendido hacer

47 AGA, caja 21/11825, expediente no 5184/57. 
literatura para adolescentes, sino que intenta - y consigue- impresionar al espectador con el primitivismo y las rudezas de Creta. PUEDE PUBLICARSE [con al margen la indicación autógrafa: "SIN TACHADURAS"].

En ambos casos se aprecia la autonomía de las diferentes secciones, ya que a la solercia correctora corresponde una interpretación menos restrictiva de la Dirección General que finalmente juzga innecesarias las enmiendas sugeridas y autoriza la publicación de las obras tal como están. Al año 1959 corresponden los expedientes relativos a las obras El pobre de Asís, Libertad o muerte y Cristo nuevamente crucificado ${ }^{48}$. Por lo que se refiere a las peticiones de publicación de Libertad o muerte y Cristo nuevamente crucificado avanzadas por la editorial Planeta el 27 de octubre de 1959, estas se conceden por mor de que se trata de obras revisadas y cuya importación ya había merecido el nihil obstat ${ }^{49}$.

Más interesante es el expediente relativo a la solicitud de publicación del reportaje Del monte Sinai a la isla de Venus. Cuadernos de viaje que Santiago Galán Conde envió el 10 de enero de $1962^{50}$. El Lector no F-27 (Mariano de la Pinta Llorente), en un informe con fecha de 11 de enero de 1962, responde a la pregunta de si la obra ataca a la moral: "Táchese lo señalado en páginas 65, 127 y 150”. Al margen aparece otra glosa manuscrita "N. L. L. 8", sigla con la que se solicitaba una nueva lectura por parte del Lector no 8. El 15 de enero de 1962, en el apartado de observaciones, el Lector F-27 había explicitado lo siguiente:

48 AGA, caja 21/12564, expedientes no 4668-59; no 4670-59; no 4671-59. En el caso de la novela sobre San Francisco, quizá merezca la pena transcribir el juicio entusiasta del padre Miguel de la Pinta Llorente, quien a primeros de noviembre de 1959 autoriza la publicación afirmando que "se trata de la mejor obra de este famoso escritor, ya extinto, y viene a ser una especie de trabajo de integración literaria, a base de la fabulosa vida de San Francisco, modo ello claro es urdido por los encantos de la fantasía literaria. Realidad y fantasía juegan aquí su destacado papel y hacen del libro un verdadero encanto" (no 4668-59).

49 Para Cristo nuevamente crucificado en 1954 (exp. 3599/54) y para Libertad o muerte en 1957 (exp. 5184-57).

50 AGA, caja 21/13707, expediente 126-62 [la caja contiene también el expediente 124-62 relativo a la publicación de la tragedia Melisa, que se autoriza sin demora alguna]. 
Una colección de artículos relatando sus impresiones de viaje por diferentes países europeos y orientales. Todos ellos llevan la garra del gran escritor griego, y aunque en geral [sic] la obra es muy estimable, debe tacharse lo suprimido en páginas correspondientes. PUEDE EDITARSE.

A raíz de lo apuntado en el informe antedicho, se somete a una segunda lectura por parte del Lector no 8 (el padre Álvarez Turienzo) quien, en el informe correspondiente (del 20 de enero de 1962), a la cuestión de si la obra ataca al Régimen y a sus instituciones contesta: "comprobadas e conformes las tachaduras 2-4-62"; y en el apartado reservado a las observaciones precisa:

Serie de impresiones de viaje, que dan motivo a consideraciones de una y otra índole. Domina el conjunto un espíritu de melancólica independencia. En ocasiones esa independencia se traduce en críticas, que afectan a formas enteras de vida. Los puntos de vista, aunque siempre personales y un tanto extrańos son admisibles, salvo en dos ocasiones, que corresponden a las páginas 150-152, en que se deja a luz peyorativa el sentido ascético del cristianismo, a propósito de la mezquita de Córdoba; y a las páginas 160-161, en que se hacen algunas consideraciones tendenciosas sobre la guerra civil española. Suprimidas esas páginas PUEDE AUTORIZARSE.

El expediente incluye las galeradas de la obra con las partes a las que se imponía la supresión tachadas en rojo. Consideramos oportuno transcribir las porciones textuales afectadas ${ }^{51}$ :

- Cap. II "Panait Istrati encuentra a Gorki”, p. 65:

"Algunos meses más tarde, nació Kyra Kyralina, la historia de esta santa prostituida que, entregándose a los hombres, realizaba su deber para con Dios. Libro lleno de pasión, de indiferencia y de un amor desenfrenado de la vida, libro alegre y dulce como un cuerpo humano".

51 Se transcriben en letra redonda las partes sin tachar y en cursiva las partes cuya supresión se solicita. 
- Cap. sobre Ávila, p. 127:

"Antes de abandonar Ávila me despido de Teresa. En otros tiempos, sin duda alguna, esta llama tomó otro aspecto, ardió de modo distinto: en la divina primavera de los tiempos presocráticos, en una isla griega, rodeada por discípulas amorosas, Teresa fué llamada Safo; asimismo, en el siglo veinte, asolado por la injusticia, el hambre y el dolor y no pudiendo agarrarse al antiguo Dios para dar en otra vida la recompensa o el castigo, la santa ha predicado ora cruzada y ha tomado otro camino".

La orientación de estas dos primeras supresiones es evidente. En el sucesivo capítulo dedicado a Córdoba (pp. 150-152) y a su joya ecuménica, la Mezquita, se juzgan poco atinadas las opiniones heterodoxas de Kazantzakis sobre el cristianismo, así como la escena del encuentro secreto entre una joven y su galán en el intercolumnio del templo, casi un locus amonus sacro-profano. Transcribimos a renglón seguido toda la parte eliminada:

"De repente levanto los ojos. Entre dos columnas, cuelga ensangrentado un gigantesco Cristo en la cruz. Lo veo en la sombra como se contorsiona de dolor. Sus cinco heridas sangran. La Virgen está desmayada a sus pies y Juan gime con un rictus atroz. No puedo mirarlo. La tierra es un sendero florido que conduce a la tumba. Se puede — como ha hecho el cristianismo- cubrir este camino con gusanos de tierra, con gusanos de la tumba e impedir así de gozar de los bienes de este mundo. Pero también se pueden separar hasta el último minuto a estos despiadados mensajeros de la muerte $\mathrm{y}$, caminando hacia la muerte con paso firme, aprovecharse de las alegrías del camino. Así lo hizo Mahoma para conducir hacia Alá a sus fieles. Contemplo esta mezquita transformada en iglesia y mientras me paseo por entre las columnas, pienso: Esta maravilla vivirá todavía muchos siglos, otra religión vendrá pues a cobijarse. El nuevo rostro de Dios brillará en la penumbra, llamado de otro modo el nuevo rostro del hombre ¿reflectará con un corazón tan alegre, un espíritu más libre, liberado de sus esperanzas metafísicas? ¿Podremos un día caminar hacia la Muerte aun sabiendo bien que no es la puerta del Paraíso sino un abismo en donde no existe la salud? ¿Y no por ello estar llenos de pánico, sino al contrario, estar enamorados de la vida, orgullosos de ser libres y felices de haber vencido por fin a la esperanza y al miedo? ¿Cuándo pues conocerás esta luminosa, digna 
y tierna adoración de la tierra? Me alejo del Crucificado. Me compadezco de esta mezquita como si se tratara de una hermosa manzana que un gusano royera lentamente. De pronto oigo unos pasos precipitados y me vuelvo. Una joven con la cabeza cubierta por su mantilla y con un abanico rojo en la mano, se desliza furtivamente de una columna a la otra y se arrodilla ante cada altar haciendo acción de rezar. Su mirada inquieta parece buscar a alguien. Mueve nerviosamente el abanico, arregla el ramo de jazmín prendido en su cabello... Repentinamente toda la iglesia se llena de su angustia. La santa mezquita rebosa de sentimiento humano. También yo quedo ganado por la angustia de la joven. Sufro con ella, espero... Pero bien pronto allá abajo, entre las columnas, aparece el amigo, los finos bigotes retorcidos. Al verlo, la joven abandona a Dios - ¿para qué le sirve ahora? - . Y corre al encuentro de su enamorado. Yo me estremezco de alegría. La mezquita adquiere por fin un sentido. El corazón, este corazón que ama a la vida, a pesar de todo es el verdadero Dios del Hombre”.

Una última tachadura aparece en el capítulo sobre la Salamanca del bando nacional (pp. 160-161), con su "antiguo palacio episcopal desde donde, invisible, vigilante, callado, el testarudo Franco gobierna ahora el destino de la joven España”. Obviamente el adjetivo "testarudo", percibido como excesivamente despectivo, relativo a la tozudez del Caudillo, cae irremediablemente. Así como el tono sutilmente irónico, mas suficientemente anticlerical, del siguiente párrafo, donde Kazantzakis ilustra con lucidez el secularismo de la Iglesia española y su vanagloriosa militancia por la causa de los más ricos y poderosos (en evidente contradicción con su mandato evangélico):

Algunos sacerdotes con sotana de raso y el rostro sonriente, fino y recientemente afeitado, con espesas cajas, caminan sin hacer ruido. Todos sus cuerpos parecen sonreír pues están convencidos de ser los vencedores. Sus raíces son ahora profundas. Miles de hombres han muerto por la Iglesia, el número de sus mártires ha aumentado, su blasón se ha dorado de nuevo. Aquí, la religión se mezcla nuevamente con los poderosos intereses de la época y entra en la vida militante contemporánea. La Iglesia española no es ya hoy una simple tradición rica en viejos pergaminos. Se ha convertido en un 
ser querido que, habiendo sido herido, circula por los corredores de los generales, entre sus amigos y muestra con orgullo sus heridas...

El tono de estos comentarios, si bien continúa en la línea de un manifiesto antidogmatismo y de una visión más pasional y humana de la espiritualidad, si por un lado carece del histrionismo burlesco de Zorba, por otro resulta mucho más grave y rotundo. Aquí ya no es el personaje de ficción quien describe y critica el hombre y sus costumbres, sino el propio autor, curioso y atento viajero, 'mártir' (en el sentido etimológico del término $)^{52}$ de las bellezas y contradicciones de su época.

Una vez corregidas oportunamente las galeradas, el editor vuelve a enviarlas con la indicación de las enmiendas y supresiones efectuadas. En este caso, como ya había ocurrido con la edición de Vida y hechos de Alexis Zorba, la versión que publica Planeta en 1962, en el tomo II de las Obras selectas, aparece depurada y retocada ${ }^{53}$.

Discurso aparte merece el destino de otra celebérrima novela de Kazantzakis que suscitó en su momento —y quizá aún hoy- encendidas polémicas: La última tentación. Sobre este libro — escrito en 1951 y cuya princeps vería la luz en Estocolmo el mismo año, cuatro antes de que se publicara en Grecia— ${ }^{54}$ sufrió, como veremos, el repudio más riguroso e inapelable de la censura eclesiástica espańola ${ }^{55}$.

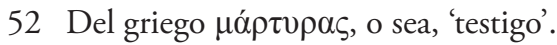

53 La versión integral puede leerse en: Nikos Kazantzakis, España y Viva la muerte, trad. Joaquín Maestre, Madrid, Júcar, 1977 y Viajando. España. ;Viva la Muerte!, pról. Eleni N. Kazantzaki, trad. del griego de Guadalupe Flores Liera, Madrid, Ediciones Clásicas, 1998. Alexandra Samouil en su estudio sobre el Quijote en Kazantzakis alude de paso, y sin más precisiones, a las discrepancias entre el texto original y la versión publicada por Planeta: "La traducción de Andrés Lupo Canaleta en la edición de las Obras selectas (vol. II, págs. 1106-1152) solo recoge parte de los textos de Kazantzakis sobre Espańa y es, además, incompleta" (cf. Alexandra Samouil, "Don Quijote en Grecia. Su presencia en la obra de Nikos Kazantzakis", en Don Quijote en su periplo universal. Aspectos de la recepción internacional de la novela cervantina, coord. Hans Christian Hagedorn, Cuenca, Ediciones de la Universidad de Castilla-La Mancha, 2011, pp. 215-233 (p. 217, nota 4).

54 Nikos Kazantzakis, Den sista frestelsen, Stockholm, Hugo Gebers Foerlag, 1952; N.

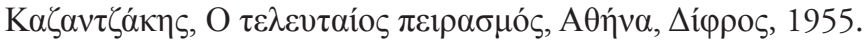

55 Como dijimos al comienzo de este trabajo (cita en las pp. 2-3), en 1954 la obra fue incluida en el Index de libros prohibidos tanto por la Iglesia Católica como por la 
Fueron dos los intentos de publicar en España la controvertida novela, y ambos quedaron frustrados — con deliberada obstinación- por la censura. El primero data de 1960, cuando el 9 de enero Santiago Galán Conde avanza una primera solicitud para la divulgación de " $L a$ dernière tentation (La última tentación), título provisional" (tirada de 2000 ejemplares $)^{56}$. A la solicitud se adjunta una copia de la edición francesa de referencia: "La dernière tentation, roman traduit du grec par Michel Saunier, París, Librairie Plon ("Colección Feux croisés âmes et terres étrangères”), 1959”. En la cubierta aparece indicado el formato y su colocación editorial en Espańa: "Obras Selectas". En la propia solicitud, al margen, en lápiz rojo y con mayúscula: "INDEX". En el expediente, dentro del apartado relativo a los "Antecedentes", asoma una sigla y una raya, al objeto de indicar que no consta antecedente alguno; y en la sección relativa al lector reza, siempre en lápiz rojo: "Pase al Lector no 25, Madrid, 12-1 de 1960". A este respecto, el sobredicho lector, que no es otro sino el mismo padre Mariano de la Pinta Llorente, formula el siguiente juicio sobre la edición francesa:

Es esta obra quizás la más importante del novelista griego Kazantzaki, y versa sobre la vida de Jesucristo. En la mente del autor la obra se escribe para realzar y despertar el amor del hombre al Crucificado; y la última tentación de Jesucristo se refiere a las sugestiones del Maligno, viéndose Maestro en frente de una vida humana feliz, disfrutando de la mujer en el matrimonio, sembrando hijos, disfrutando de la estimación de los hombres etc. etc. Ya puntualizamos cómo el autor escribe la novela con el intento de que el lector ame más a Jesucristo. Se trata como es lógico, de un trabajo de integración literaria extraordinario, pero como tal aún partiendo de los textos escriturarios, el autor aporta con su talento la ficción y la novela. Siendo España país católico, y en virtud del Derecho Canónico y del Concordato que le respalda, al tratarse de la adorable persona de Jesucristo, es exigencia indeclinable el que esta obra lleve la licencia eclesiástica, y por lo tanto nuestro Departamento no debe autorizar su publicación, sin

Ortodoxa. A tal decisión Kazantzakis replicó con lúcida y orgullosa dignidad: envió telegrafiada al tribunal eclesiástico romano la conocida cita de Tertuliano "Ad tuum, Domine, tribunal appello". Véase la nota 3.

56 AGA, caja 21/12630, expediente 75-60. 
el refrendo de la autoridad de la diócesis donde el libro vaya a ser editado. Sin esta condición NO DEBE AUTORIZARSE ${ }^{57}$.

El juicio no sólo es benévolo (como sugería Abellán), sino celebrativo de la extraordinaria capacidad de Kazantzakis por escudriñar la doble pasión, humana y divina, de Cristo, siendo el objetivo primario de la novela el de estimular el amor del hombre hacia el Crucificado. Por otra parte, el agustino no pasó por alto el posible impacto del libro en un contexto de acogida potencialmente hostil: el de una España católica dogmática y conservadora que se apoyaba y se alimentaba del propio ordenamiento jurídico-político que la sostenía. Haciendo nuestra la metáfora evangélica, diríamos entonces que en su informe Mariano de la Pinta Llorente adoptó una actitud en cierto modo "pilatiana», ya que, si por un lado brinda su personal y positivo juicio de la novela, por el otro remite al juicio inderogable del tribunal eclesiástico.

Quien le sucedió sería menos permisivo. El informe, firmado el 20 de julio de 1963 por el lector no 8 (padre Álvarez Turienzo), se cifra en un juicio taxativo:

Un Jesús puro hombre, que pasa por todas las angustias y tentaciones de los hombres, incluida la tentación carnal, con una interpretación libérrima de los Evangelios, ajena al dogma y contraria en ocasiones a él; dando por esencia de la persona y mensaje de Jesús el propio de un "hombre de Dios", pero con descuido incluso en oposición al plano sobrenatural... Un libro en estas condiciones, centrado sobre una cuestión eminentemente dogmática y moral, que además, y comprensiblemente, se halla incluido [en] el Índice. NO DEBE SER AUTORIZADO.

La denegación final llegaría en efecto el 27 de julio de 1963. Dicho informe incluye también una hoja-epílogo con los datos del expediente ${ }^{58}$ y la consiguiente solicitud del editor de Planeta pidiendo la revisión:

57 El informe lleva fecha del 12 de febrero de 1960. En el resto del documento no aparecen más datos fehacientes.

58 "75-60 — sin ejemplar- // 1 de junio de 1963 // LA ULTIMA TENTACION - Nikos Kazantzaki // 27 julio 63 [y una sigla en bolígrafo] // PLANETA - Barcelona” (cf. AGA, caja 21/12630, expediente 75-60). 
Sea REVISADO, con el fallo correspondiente definitivo, el expediente 75-60, "LA DERNIERE TENTATION" (La última tentación), del autor Nikos Kazantzaki, que fue presentado a la previa Censura el 9 de enero de 1960, solicitando la autorización para editarla, según Orden del 29 de abril de 1938 y disposiciones complementarias, sin que hasta el presente hayan dado fallo definitivo; únicamente, y de forma verbal, nos comunicaron por ventanilla que se presentara Certificado de Censura Eclesiástica, para poder dar dicho fallo definitivo. Como la Editorial PLANETA, por las razones que ignoramos, no presenta dicho certificado de Censura Eclesiástica y teniendo presente que nuevas normas, al aparecer, rigen los actuales trámites de Censura de libros, es por lo que rogamos la REVISIÓN de dicho expediente. Dios guarde a V. I. muchos ańos. Madrid 1 de junio de $1963^{59}$.

El 23 de diciembre de 1960 la Dirección de Información recibió asimismo la solicitud para la importación de 50 ejemplares de la novela La última tentación — publicada por la Editorial Sur de Buenos Aires-, enviada por el gerente de la Editora y Distribuidora Hispano-Americana S.A. (EDHASA) de Barcelona ${ }^{60}$. Al margen se lee en claras letras: "denegada INDEX 29-XII-60”. En dicho expediente, en el espacio reservado a los antecedentes, reza: "75/60 en trámite", y una sigla; y en el espacio relativo a la asignación del Lector figura en letra mayúscula: "INDEX Madrid, 27 de XII de 1960”. En la sección relativa a la resolución final, se indica: "DENEGADA POR HALLARSE INCLUIDA EN EL INDEX, Madrid 27 de diciembre de 1960 y más abajo se precisa que "la obra a que se refiere este expediente puede ser denegada. Madrid, 27 de diciembre de 1960". El expediente incorpora a su vez la lacónica respuesta que la sección Inspección de libros del Archivo del Ministerio de Información y Turismo le envía al editor: "NO PROCEDE SU IMPORTACIÓN"; y una papeleta blanca sellada, en la que se declara: "He recibido el ejemplar titulado LA ÚLTIMA TENTACIÓN DE NIKOS KAZANTZAKI correspondiente al expediente 6761-60 que retengo para su lectura.

59 Arriba en el margen izquierdo de la hoja aparece escrito a mano: "antecedentes 8 [en rojo] 6/1807/63". Más abajo se lee “Denegado 27-VII-63".

60 AGA, caja 21/13095, expediente 6761-60. 
Madrid, 27 de diciembre de 1960. Firmado: J. Rumeu de Armas”. En la papeleta azul canónica se resumen los datos relativos al expediente y a su epílogo: "Denegada en 4 de Enero de 1961"61.

Un lustro más tarde, en 1966, la Editorial Planeta volvería a la carga, enviando otra copia de la edición parisina de La dernière tentation, acompañada esta vez por una carta, fechada a 23 de febrero de 1966 y enderezada a Faustino Sánchez García, Jefe de Censura de la Sección de Libros (con sede en Madrid en la significativa Avenida del Generalísimo no 39$)^{62}$ :

\section{Querido amigo:}

Tenemos suspendida por la Censura la obra de Nikos Kazantzaki LA ÚLTIMA TENTACIÓN, que ha sido publicada en todos los países del mundo y ha constituido uno de los mayores éxitos del autor. Yo solicité dicha autorización para que fuera incluida en el tomo tercero de sus Obras Selectas, y me encuentro con que no tengo material suficiente para hacer dicho tomo si no me autorizan la obra. Le he indicado a nuestro representante para la censura en Madrid, don Santiago Galán, que pida nueva revisión, y espero que Usted estudie este asunto con todo cariño, a fin de poder ultimar la edición del tomo tercero de las Obras Selectas de este autor.

Reciba un fuerte abrazo de su buen amigo,

\section{P. Ricardo Herrero Velarde}

El tono insistente, aunque ciertamente amistoso, con el que Herrero Velarde se dirige al Director de Censura revela la firme resolución de completar el tomo tercero de las Obras selectas hacía tiempo programado. En el expediente 2058-66 se recoge a su vez la solicitud para la publicación enviada por Planeta el 8 de marzo de 1966, en cuyo margen superior izquierdo se lee la frase "autorizada para Obras Selectas", luego tachada y sustituida por la indicación: “24.III.66 Fajardo Denegado”. Entre los antecedentes, se alude al expediente previo de 1960: “6761-60 Den. P.B.”.

61 Nos permitimos seńalar cómo, a lo largo y ancho de todo este caudal de números, la máquina burocrática del Ministerio no dejó de mover sus engranajes ni siquiera en épocas festivas. Véase, por ejemplo, la fecha del informe relativo a la novela Toda-Raba (cf. nota 25), redactado el día de Navidad de 1959.

62 AGA, caja 21/17192, expediente 2058-66. 
En esta segunda etapa de su viaje, la novela fue sometida a la revisión del Lector no 21: una vez más el padre Álvarez Turienzo. En la sección del informe relativa a las observaciones, firmada el 23 de marzo de 1966, el religioso escribió:

Véase en hoja aparte el informe de conjunto. La obra es, desde el punto de vista dogmático, inaceptable. Tratándose de una novela, es decir, de una obra de imaginación — no histórica ni doctrinal¿cabe tener con ella una benignidad de otro modo inadmisible? Si desde el punto de vista de la ortodoxia es recusable, en un plano puramente humano-natural encierra valores indiscutibles. Un cristiano mediamente instruido ve desde la primera página que lo que se nos dice en ella no puede ser admitido a la letra; por lo que, para la mayoría, su lectura no parece que pueda resultar gravemente perturbadora. Aunque no cabe duda que en nuestro mundo falto de claridad y de doctrinas afirmativas de creencias definidas ha de obrar debilitando el sentido de la fe consagrada. Con los reparos que circunstancias semejantes imponen PODRÍA AUTORIZARSE.

El juicio de Álvarez Turienzo, que tres años antes había redactado otro no del todo destructivo, aunque sí solicitando la denegación (expediente 7560 ), se ablanda un poco más, en la medida en que enfatiza el componente de ficción literaria del texto, con todo lo que ello implica en términos de libertad de expresión artística. Su orientación positiva y posibilista indujo, empero, a la Dirección a solicitar un tercer informe, según se desprende de la sigla "N.L.6" al margen del que nos ocupa. La tarea recayó sobre un nuevo lector, ahora el no 6 . En la sección final de su testimonio, asoma una primera indicación en rojo (“denegación”) luego borrada y sustituida por la frase, escrita con bolígrafo azul, "autorización para Obras Selectas Fajardo". Intercalada se halla la carta que el Director General de Información le había enviado al editor de Planeta el 7 de abril de 1966:

En contestación a su instancia de 23 de febrero de 1966 y previos los pertinentes informes del Lectorado de esta Sección, lamento comunicarle que no ha sido posible conceder la autorización de la obra LA ULTIMA TENTACIÓN - Nikos Kazantzaki. Lo que traslado a $\mathrm{Vd}$. para su conocimiento y efectos, indicándole que contra la presente resolución puede interponer recurso de revisión, dentro 
del plazo de 15 días hábiles, a contar del siguiente de la presente notificación. Dios guarde a $\mathrm{Vd}$. muchos años.

En dicho informe, contenido en el expediente 2058-66, tenemos el juicio del Lector no 6, al que la obra le llegó el 25 de marzo de 1966:

¿Ataca al Dogma? sí páginas. Véase nota adjunta

¿A la moral? no

¿A la Iglesia o a sus Ministros? no

¿Al Régimen y a sus instituciones? no

¿A las personas que colaboran o han colaborado con el Régimen? no Los pasajes censurables ¿califican el contenido total de la obra? sí Informe y otras observaciones: Véase nota adjunta.

En la nota anexa, mecanografiada, se lee:

JHS. / LA ÚLTIMA TENTACIÓN. C. Novela religiosa. / La obra está inspirada en la narración evangélica de la vida de Cristo pero compuesta con mucha libertad. Es un poeta que hace un poema en prosa inventando hechos y palabras que pone en boca de Cristo para darnos la imagen que él quiere. En verdad es un canto de amor y entusiasmo a la figura humana del Redentor pero ya sea por ignorancia teológica, aunque más bien parece por falta de fé, despoja a Cristo de su divinidad y lo considera tan solo como un hombre, con las pasiones y faltas propias de la humana naturaleza. Toda la obra resulta llena de ideas erróneas que son verdaderas blasfemias teológicas contrarias a la doctrina cristiana y verdaderamente escandalosas para los fieles creyentes. / Cristo es un iluminado que se cree enviado por Dios para salvar el mundo por medio del amor pero está sujeto a las mismas pasiones que los demás hombres, aunque siempre resulta vencedor sin dejarse llevar por ellas; siente amor carnal por la Magdalena pero se conserva puro en medio de las ocasiones en que esta mujer pretende hacerle caer; en la cruz siente la última tentación, siente que Dios le ha abandonado y piensa que quizá hubiera sido mejor haberse casado con la Magdalena y su hermana Marta, puesto que está permitida la poligamia a los judíos y vivir tranquilo en $\mathrm{Na}$ zaret con sus esposas e hijos y no haber pretendido salvar al mundo por los dolores de la cruz pero también vence esta última tentación y se encuentra gozoso clavado al madero cumpliendo la misión 
que Dios le ha encomendado y llegando a ser para los desdichados hombres la encarnación del Hijo de Dios. / Véase la lista de errores y herejías que saltan a la vista en esta obra. Cristo en su juventud se dedica a hacer cruces para la ejecución de los reos y el mismo forma parte de los verdugos pág. 49. La S. Virgen desea que Cristo se case pág. 61. Cristo siente tentaciones sensuales pág. 80. Cristo confiesa que él tiene muchas faltas pág. 89 y 147 . Cristo siente deseos sensuales al ver a la Magdalena pág. 91. Cristo pasa una noche en la habitación de la Magdalena cuando esta es pecadora pública aunque él no es vencido por la tentación pág. 96. Cristo niño inicia a la Magdalena en placeres sensuales pág. 147. Cristo se admira de que él pueda hacer milagros pág. 339. Cristo no sabe que el Mesías debe de sufrir la cruz pag. 408. Cristo niega la historicidad de los Evangelios escritos pág. 142. $\underline{\text { Cristo }}$ organiza de acuerdo con Judas la traición y entrega a los judíos pág. 444. Cristo se imagina que está besando la boca de la Magdalena pág. 483. Cristo desea tener hijos de la Magdalena pág, 483. Cristo desea también casarse con Marta pág. 493. La divinización de Cristo es obra de San Pablo pág. 503. La resurrección de Cristo es un mito predicado por San Pablo págs. 305 y 506 . Como se ve, aquí se ataca a la verdad fundamental del cristianismo por lo cual no es de extrañar que esta obra haya sido incluida en el Índice por la Iglesia Católica y condenada tambíen por la Iglesia Ortodoxa Griega a pesar de ser su autor el más famoso de los escritores griegos contemporáneos. Creo por tanto que no conviene la publicación en castellano de esta obra ${ }^{63}$.

El informe lleva la firma autógrafa del Censor Jefe Francisco Aguirre ${ }^{64}$ y fecha de 15 de abril de 1966. En el verso del folio, el siguiente texto manuscrito, firmado por el propio Fajardo el 16 de abril de 1966:

Las repetidas afirmaciones que hace el autor respecto de Cristo incurren de lleno en los artículos 209 y 293 del C.P. por constituir blasfemia. Pues Cristo y Dios son uno y mismo. / La jurisprudencia del T.S. es abundante y perentoria. / Cf. 50 T.S.; 24.VI.1954, 17-

63 El subrayado es del propio lector.

64 Sobre el sistema de los lectores-censores en los años sesenta, véase: Francisco Rojas Claros, Dirigismo cultural y disidencia editorial en España (1962-1973), Alicante, Servicio de Publicaciones de la Universidad, 2013, pp. 52-55. 
XI-1959, 15-XI-1960, 5.VII.1916, 9.X.1888 etc. etc. etc. / Aparte de que "la nación española considera como timbre de honor el acatamiento de la Ley de Dios, según la doctrina de la Santa Iglesia Católica, Apostólica y Romana" [subrayado en rojo] de la ley de Principios del Movimiento Nal. (17.V.1958) y es claro que las especies contenidas en este escrito de Kazantzaki van en contra de esta doctrina. / El libro NO DEBE publicarse [subrayado dos veces]".

En razón de este juicio perentorio y sin posibilidad alguna de apelar, el informe concluye con la resolución, firmada el 18 de abril de 1966: se deniega definitivamente la publicación.

Sin embargo, el recorrido de La última tentación por los meandros de la censura franquista no ha concluido todavía. El expediente 3556-66 brinda los términos del postrer acto de este largo viaje, a la luz de los siguientes documentos ${ }^{65}$ :

- Una copia de la ya citada edición francesa de Plon de 1959.

- La solicitud para la publicación, enviada el 11 de mayo de 1966 por Santiago Galán Conde, de la Editorial Planeta, en cuyo margen aparece en lápiz rojo: "NO PUBLICABLE 12-V-1966 FAJARDO".

En la sección del informe dedicada a los Antecedentes reza: "2058-66 Denegada 18-11-66”, seguida por una firma poco legible. En el espacio reservado al número del Lector aparecen un guion en rojo y una F mayúscula, también en rojo y subrayada, siglas que apuntan al mismo Fajardo. La fecha es de 12 de mayo de 1966. En las observaciones del lector consta lo siguiente: "Copia del informe emitido en expediente 2058-66 a LA ULTIMA TENTACION por el Lector Rvd. P. Aguirre en fecha 15-466”. Una línea en bolígrafo rojo remite a sendas hojas mecanografiadas y grapadas que contienen el texto integral del informe previo de Aguirre y llevan la firma de Fajardo en mayúscula, seguida de la fecha: 16 de abril de 1966. La frase con la que finalizaba el primer informe está borrada y una flecha indica que se precisa ańadir en aquel punto la parte mecanografiada de la segunda hoja, que transcribe a pies juntillas el texto antes

65 AGA, caja 21/17349, expediente 3556-66. 
citado de Fajardo, sufragado por las referencias jurídicas y rubricado el 16 de abril de 1966. La resolución final establece, de forma terminante, la denegación a la publicación. En el documento de síntesis, firmado por el Director General de Información y enviado al editor el 17 de mayo de 1966, se apostilla: "En contestación a su consulta del 11 de mayo de 1966 se le comunica que no es aconsejable la edición de la obra titulada "LA ULTIMA TENTACION” Nikos Kazantzaki”.

La novela nunca aparecería, en efecto, dentro del tomo tercero de las Obras selectas de Kazantzakis auspiciadas por Planeta. Habría que esperar hasta finales de los ochenta para que hiciera su entrada oficial en el panorama español: Nikos Kazantzakis, La última tentación, traducción de Roberto E. Bixio, Madrid, Debate, 1988 (que recupera la versión editada por Carlos Lohlé en 1973) ${ }^{66}$.

En conclusión, el periplo odiséico de la obra del gran escritor griego a través de las procelosas aguas de la censura franquista nos ofrece un buen ejemplo de la extremada articulación del proceso de revisión, realizado con extrema y documentada meticulosidad por el Ministerio de Información y Turismo. Además, transparenta las consecuencias de este proceso, que no solo condicionó en su momento la lectura de determinadas obras (prohibiéndolas o depurándolas), sino que continúa repercutiendo hoy día, habida cuenta que aún circulan, en paralelo a las integrales, aquellas otras versiones revisadas y amoldadas al canon del franquismo.

66 Para más inri, aquel mismo año (1988) la obra padeció una segunda forma de censura al prohibirse la adaptación cinematográfica, dirigida por Martin Scorsese, durante la dictadura de Pinochet; o sea, en el mismo país, Chile, que por vez primera había dado voz en castellano a la obra de Kazantzakis y que hoy impulsa con renovados bríos la investigación sobre el cretense. Remitimos al Centro de Estudios Griegos, Bizantinos y Neohelénicos "Fotios Malleros" de la Universidad de Santiago de Chile. En 1996, al levantarse la prohibición, un grupo de ultraconservadores elevó una causa contra el estado en la que de nuevo solicitaban la censura del filme. El caso alumbró una sentencia que pertenece ya a la literatura jurídica en materia de libertad de expresión. Véanse Yubi Cisneros, La libertad de expresión en el Sistema Interamericano, en Libertad de expresión. Una discusión sobre sus principios, limites e implicaciones, eds. Carlos Correa, Moraima Guanipa, Yubi Cisneros y Andrés Cañizález, Caracas, Los Libros del Nacional, 2007, pp. 57-63; A. Gómez-Robledo, "Caso: La última tentación de Cristo (Olmedo Bustos y Otros) vs. Chile. Sentencia del 5 de frebrero de 2001", Cuestiones Constitucionales, 25 (julio/diciembre 2011), pp. 333-338. 
El prestigio de las Obras selectas de Planeta se interpreta como garantía de un producto cuidado y útil a la hora de acercarse a la lectura o al estudio crítico de unas obras estimadas ya como uno de los clásicos de la literatura del Novecientos. Y en cambio, lo es sólo parcialmente, según acabamos de demostrar.

Si como sugiere Abellán, existe un nivel latente e inefable, aunque no menos relevante, de control sobre los textos, que pone sobre la mesa la responsabilidad de las propias editoriales ${ }^{67}$, también es verdad que la circulación del verbo de Kazantzakis por España, más que a la "gran benevolencia" 68 del aparato de censura, se debe al especial y encomiable ahínco con el que Planeta se afanó en sacar a la luz un corpus representativo de su producción. Por otro lado, las intervenciones y alteraciones respecto a las versiones integrales hispanoamericanas son —como acabamos de ver - relativamente escasas y no merman el sentido intrínseco del pensamiento del escritor griego. Sin embargo, consideramos oportuno, desde una perspectiva filológica, exhumar los desvíos de los textos censurados respecto al arquetipo — como en Vida y hechos de Alexis Zorba - para que el público sea consciente del proceso al que se sometió la edición a la que posiblemente acuden.

Llegados a este punto, cerraremos nuestro trabajo con la voz límpida, y sin filtros, del propio Kazantzakis cuando - durante su estancia en la España republicana - reflexionaba, no sin evidente amargura, sobre la hostilidad del mundo editorial helénico hacia sus escritos:

Todo ha sido siempre organizado contra mí. Y a la vista de tantos enemigos, me he sentido presto, alegre, despectivo, silencioso, $\mathrm{y}$, por fin, victorioso. Mis amigos me creen dichoso porque ignoran las luchas que han precedido a la victoria, porque no saben que mi dicha es la flor de mi desesperación y de mi desprecio a todas las cosas terrenas; yo no soy un rebelde romántico, un místico que

67 " [...] Los efectos de la censura editorial no deben pasarse por alto, ya que, si bien sus causas son un tanto oscuras, no puede ignorarse, empero, el importante papel que ha desempeñado este tipo de censura. [...] Dado el recelo reinante entre los editores, nunca probablemente se podrá averiguar el papel y la medida en que su actitud ha contribuido a paralizar o promocionar, podar o modificar determinadas obras" (Manuel L. Abellán, op. cit., p. 97).

68 Ibidem, p. 184. Consideración referida especialmente al tomo I de las Obras selectas. 
desprecia la vida ni un insolente que lucha contra la materia. Amo la vida, la tierra, el Hombre, el animal, las cosas efímeras. Tengo perfecta conciencia de su valor, pero también de sus límites. No me siento poseído por ninguna ilusión, no he caído en ninguna trampa, pese a entrar en todas ellas, como una rata muy ligera que entra en la ratonera, come el cebo depositado al fondo para atraparla y se va hacia otras trampas sabiendo bien que le espera la última, la trampa de la muerte, y que entrará en ella para ya no salir más ${ }^{69}$.

Sin embargo — como sugiere el ensayo de Bidal-Baudier ${ }^{70}$ — ni las muchas censuras que Kazantzakis sufrió en vida ni la última e inexorable trampa de la muerte pudieron clausurar su espíritu libre y tampoco silenciar su memoria. Hoy más que nunca, en los umbrales del siglo XXI, debemos celebrar la figura de este magnífico 'cuerdo-loco', mientras resuena en nuestros oídos el alegre y vibrante eco del saludo con el que el cretense, en su nutrida correspondencia, solía despedirse — en lengua castellanadel amigo Prevelakis: “Para siempre!”.

69 Carta a Eleni Samios fechada en Madrid a 6 de noviembre de 1932. Cf. Eleni N. Kazantzaki, op. cit., p. 209.

70 Marie-Louise Bidal-Baudier, Nikos Kazantzaki. Comment l'homme devient immortel, París, Plon, 1974. 